\title{
Læren af Mali
}

Krisen i Mali har afsløret manglerne ved den multilaterale sikkerhedsarkitektur i den vestafrikanske samarbejdsorganisation Ecowas, Den Afrikanske Union (AU) og FN. Det første svar efter militærkuppet i Mali i marts 2012 var en beslutning om at udstationere en multidimensional Ecowas-mission, Micema. Det blev ved planerne. Så kom AU's initiativ til en afrikansk ledet mission i Mali (Afisma), som der heller ikke kom meget ud af. $\mathrm{Og}$ så greb Frankrig ind.

Vurderet ud fra målet, at trænge jihadisters offensiv tilbage, har den franske intervention været en succes, men der mangler en exitstrategi, for problemerne er langt fra løst. Jihadisterne truer stadig, men endnu værre er nok, at landet, der er på størrelse med Frankrig og Tyskland tilsammen, ikke hænger sammen.

Politisk kaos gav tuaregerne i nord mulighed for at etablere et eget separatistisk styre, og islamistiske krigere med erfaringer fra regionens mange krige strømmede ind. Da Frankrig greb ind kontrollerede separatisterne to tredjedele af Mali. Social uro i Mali har historiske rødder i kravene fra tuareger, men den transformation af det afrikanske kontinent, som er foregået over de sidste ti år, spiller også en enorm rolle.
Mali er en central brik som mellemstation mellem Afrikas kritiske regioner, Maghreb, Sahel, Sahara og Guinea Golfen, et ressourcerigt land, hvor fremtidige konflikter uundgåeligt vil udspille sig. Uberørte uranreserver i områder, hvor tuaregerne bor, er en af grundene til stor støtte til en uduelig regering.

Fokus på terrorisme alene risikerer at bortlede opmærksomheden fra Malis største problemer: Korruption og elendig regeringsførelse. Det internationale samfund må presse og støtte Malis regering til at tage reelt ansvar. Den må søge kompromis med repræsentanter for alle samfundsgrupper og minoriteter og sikre, at selv de mest isolerede områder føler sig inkluderet. I den sammenhæng må der også tages hensyn til de enorme grænseområder, hvor strømmen af våben og militante grupper fortsat er intensiv. International Crisis Group slår fast, at uden regionale sikkerhedsmekanismer, der involverer alle Nord- og Vestafrikas lande, vil enhver sejr over terrorisme, ekstremisme og narkohandel i Mali kun være midlertidig. Danmark har bidraget med et Hercules transportfly til støtte for franskmændene imod terrorister. Hvad med en dansk indsats for Malis befolkning?

\section{Redaktionen}

